\title{
Alkaline protease production from alkalophilic Bacillus sp. isolated from natural habitats ${ }^{\text {is }}$
}

\author{
H. Genckal ${ }^{\mathrm{a}}$, C. Tari ${ }^{\mathrm{b}, *}$ \\ a Biotechnology and Bioengineering Programme, Izmir Institute of Technology, Urla, Izmir 35430, Turkey \\ ${ }^{\mathrm{b}}$ Department of Food Engineering, Izmir Institute of Technology, Gulbahce Campus, Urla, Izmir 35430, Turkey
}

Received 18 January 2005; received in revised form 29 November 2005; accepted 8 December 2005

\begin{abstract}
Bacillus strains isolated under extreme alkaline conditions (Izmir, Turkey), were screened and identified for high alkaline protease activity. Strains with high protease yields were optimized with respect to inoculum concentration, temperature, agitation speed, initial medium $\mathrm{pH}$ and incubation time. Three Bacillus strains coded as I18, L18 and L21 showed high potential, for alkaline protease activity (160-222 U/ml) among 85 isolates. The specific growth rates were estimated from the growth curves as $0.49 \mathrm{~h}^{-1}$ for I18, as 0.6 and $0.7 \mathrm{~h}^{-1}$ for L18 and L21, respectively. The optimum temperatures were determined as $30^{\circ} \mathrm{C}$ for strain $\mathrm{I} 18$ and $37^{\circ} \mathrm{C}$ for the strains L18 and L21. Similarly, the optimum agitation speeds were $100 \mathrm{rpm}$ for $\mathrm{I} 18$ and $180 \mathrm{rpm}$ for L18 and L21. For all three strains, the optimum inoculation ratio and incubation time, were determined as $5 \%(\mathrm{v} / \mathrm{v})$ and $96 \mathrm{~h}$, respectively. The optimum initial media $\mathrm{pH}$ was found as $\mathrm{pH} 10$ for strain L18 and L21. Bacillus sp. L21 with the highest specific protease activity $(60 \mathrm{U} / \mathrm{mg}$ protein) and a broader $\mathrm{pH}$ range was chosen for further study. The biomass and product yield for this strain was determined as $0.023 \mathrm{~g}$ cell/g glucose and $0.021 \mathrm{U} / \mathrm{g}$ glucose, respectively. The crude enzyme of this strain was further characterized and was determined as a bleach stable, serine alkaline protease with an optimum temperature of $60^{\circ} \mathrm{C}$ and a pH of 11 , with a potential to be a candidate for the applications in the detergent industry.
\end{abstract}

(c) 2005 Elsevier Inc. All rights reserved.

Keywords: Alkaline protease; Bacillus sp.; Microbial enzymes; Enzyme production

\section{Introduction}

Proteases constitute $60-65 \%$ of the global industrial enzyme market most of which are alkaline proteases [1]. Most of these find applications in the food industry, in the meat tenderization process, peptide synthesis, for infant formula preparations, baking and brewing. Furthermore, they are used in pharmaceuticals and medical diagnosis, in the detergent industry as additives, as well as in textile industry in the process of dehairing and leather processing [2]. Currently a large proportion of the com-

\footnotetext{
This work proposes the optimization of the fermentation conditions of three Bacillus sp. isolated from natural habitats producing alkaline proteases. After the optimization process one isolate, coded L21 exhibiting high alkaline protease activity is chosen as the strain for further study. It is highly important to discover enzymes with novel properties, from species living under extreme conditions which could have wide industrial applications. Therefore this study is the initial work performed on such species and an initial step for further optimization processes.

* Corresponding author. Tel.: +90 232 7506316; fax: +90 2327506196.

E-mail address: canantari@iyte.edu.tr (C. Tari).
}

mercially available alkaline proteases are derived from Bacillus strains $[3,4]$. The reason for this is their high $\mathrm{pH}$ and temperature stability. Alkaline proteases belong to the group of proteases, which have either a serine center or are of metallo-type, exhibiting a wide $\mathrm{pH}$ range of $\mathrm{pH} 6-13$. Among these are the serine proteases with industrial importance [3]. Few examples reported in the literature, are the studies conducted by Rebecca et al. [5], who produced a high nutritional value fish hydrolysate using $B$. subtilis protease, and O'Meara and Munro [6], who used commercial alkaline protease in the upgrading of lean meat waste to edible products. Another example is the application of the alkaline protease by Tanimoto et al. [7] in the enzymatic modification of zein to produce a non-bitter peptide fraction with high Fischer ratio for patients with hepatic encephalopathy.

Given the wide application of this enzyme, it is reported that in year 2005 the global proteolytic enzyme demand will increase dramatically to $1.0-1.2$ billon dollars [8]. Therefore, taking this demand into account and knowing the geographic richness and biodiversity of our local environment with less industrial pollution, it is assumed that there is potential for alkalophilic 
Bacillus species living in these environments. Discovering such species, producing proteases with novel characteristics will be of great value to the enzyme industry for different applications. With this as main objective, local soil of Izmir region and by-products of a leather industry working under highly alkaline conditions were screened for the isolation of these strains. Total of 85 isolates were screened for high alkaline proteolytic activity according to the method described by Horikoshii [9] and only three of them showed such a potential. These strains were coded as I18, L18 and L21. In this study, the goal was to further optimize the fermentation conditions of these strains whose phenotypic and genotypic identifications were completed and choose the strain with highest alkaline proteolytic activity, which could be a potential candidate for industrial use [10].

\section{Materials and methods}

\subsection{Organisms and culture conditions}

Under the direction of the Department of Biology at Izmir Institute of Technology, Bacillus sp. L18 and L21 were isolated from the by-products of a leather factory. Similarly, Bacillus sp. I18 was isolated from the soil of the campus by the Biology Department of Ege University. The phenotypic and genotypic studies of all three strains were completed by the Department of Biology at Izmir Institute of Technology [10].

These microorganisms were cultivated in a solution containing $1 \%$ glucose, $0.5 \%$ yeast extract, $0.5 \%$ peptone, $0.1 \%$ potassium dihydrogen phosphate, $0.02 \%$ magnesium sulfate and $1 \%$ sodium carbonate where sterile sodium carbonate was added aseptically after the sterilization process. This formulation is known as Horikoshii reference medium [9]. For the solid media preparation $1.5 \%$ of agar was added to this formulation. Cultures were regenerated every 2-3 weeks on a fresh plate from the frozen stock culture. All assays were performed using the cell-free supernatant of the fermentation broth. The cell densities were determined by reading the optical densities at $600 \mathrm{~nm}$ and performing viable cell counts on the total broth. Biomass was also determined by drying the pellet obtained after centrifugation (at $5000 \mathrm{rpm}$ for $10 \mathrm{~min}$ ) at $65^{\circ} \mathrm{C}$ for $24 \mathrm{~h}$ until it reached equilibrium weight. The cell-free supernatant was used to determine proteolytic activity, protein content and carbohydrate content.

\subsection{Assay for proteolytic activity}

Alkaline protease activity was determined by applying a modified form of the method given by Takami et al. [11]. According to this procedure $0.25 \mathrm{ml}$ of glycine: $\mathrm{NaCl}: \mathrm{NaOH}(50 \mathrm{mM}$, pH 10.5) buffer was incubated with $2.5 \mathrm{ml}$ of $0.6 \%$ casein (Merck) dissolved in the same buffer at $30^{\circ} \mathrm{C}$ until equilibrium was achieved. An aliquot of $0.25 \mathrm{ml}$ of the enzyme solution was added to this mixture and incubated for $20 \mathrm{~min}$. The reaction was stopped by adding $2.5 \mathrm{ml}$ TCA solution $(0.11 \mathrm{M}$ trichloroacetic acid, $0.22 \mathrm{M}$ sodium acetate, and $0.33 \mathrm{M}$ acetic acid). After $10 \mathrm{~min}$ the entire mixture was centrifuged at $5000 \times \mathrm{g}$ for $15 \mathrm{~min}$. The supernatant in the amount of $0.5 \mathrm{ml}$ was mixed with $2.5 \mathrm{ml}$ of $0.5 \mathrm{M}$ $\mathrm{Na}_{2} \mathrm{CO}_{3}$ and $0.5 \mathrm{ml}$ of Folin-Ciocalteu's phenol solution and kept for $30 \mathrm{~min}$ at room temperature. The optical densities of the solutions were determined with respect to the sample blanks at $660 \mathrm{~nm}$ using Varian Cary Bio 100 spectrophotometer. For these studies, one alkaline protease unit was defined as the enzyme amount that could produce $1 \mu \mathrm{g}$ of tyrosine in 1 min under the defined assay conditions.

\subsection{Total protein content}

The total protein contents of the samples were determined according to the method described by Lowry [12]; the protein standard was bovine serum albumin (Sigma).

\subsection{Total carbohydrate content}

Total carbohydrate content was determined according to the phenol-sulfuric acid method [13]. The analytical grade materials were obtained from Sigma (St. Louis, USA). All the presented results were obtained from the average of two parallels.

\subsection{Characterization of the crude protease enzyme}

The crude protease obtained from the Bacillus sp. L21, which showed the highest potential for proteolytic activity, was further subjected to preliminary characterization study. Therefore, the effect of $\mathrm{pH}$ and temperature on activity and stability with the effect of various oxidizing agent, metal ion and inhibitors were studied. The procedures are outlined in detail below.

\subsubsection{Effect of $\mathrm{pH}$ on activity and stability of protease}

The effect of $\mathrm{pH}$ on the proteolytic activity of crude alkaline protease from Bacillus sp. L21, was determined by assaying the enzyme activity at different $\mathrm{pH}$ values ranging from 4.0 to 13.0 using the following buffer systems: acetate $(\mathrm{pH}$ 4.0), phosphate ( $\mathrm{pH} 7.0)$, Tris- $\mathrm{HCl}(\mathrm{pH} 9.0)$, glycine- $\mathrm{NaOH}(\mathrm{pH} 10.5-11)$ and $\mathrm{KCl}-\mathrm{NaOH}$ ( $\mathrm{pH}$ 13.0). The concentration of each buffer was $0.1 \mathrm{M}$. The relative activities were based on the ratio of the activity obtained at certain $\mathrm{pH}$ to the maximum activity obtained at that range and expressed as percentage. The $\mathrm{pH}$ stability of the enzyme was investigated in the $\mathrm{pH}$ range of 4.0-13.0. Therefore, $2 \mathrm{ml}$ of the crude enzyme was mixed with $2 \mathrm{ml}$ of the buffer solutions mentioned above and incubated at $30^{\circ} \mathrm{C}$ for $2 \mathrm{~h}$. Afterwards, aliquots of the mixtures were taken to measure the residual protease activity (\%) with respect to the control, under standard assay conditions.

\subsubsection{Effect of temperature on activity and stability of protease}

The effect of temperature was determined by incubating the reaction mixture (pH 10.5) for $20 \mathrm{~min}$ at different temperatures ranging from 30 to $80^{\circ} \mathrm{C}$. The relative activities (as \%) were expressed as the ratio of the proteolytic activity obtained at certain temperature, to the maximum activity at the given temperature range. In order to determine the thermo stability of the enzyme, experiments were conducted by measuring the residual activity after incubation at various temperatures ranging from 30 to $60^{\circ} \mathrm{C}$, for 30 and $60 \mathrm{~min}$, in the presence and absence of $0.05 \mathrm{M} \mathrm{Ca}^{2+}$ ion.

\subsubsection{Effect of oxidizing agent, metal ion and inhibitors activity of protease \\ The effects of $\mathrm{Ca}^{2+}$ ion as a metal ion, $\mathrm{H}_{2} \mathrm{O}_{2}$ as an oxidizing agent, EDTA and PMSF as inhibitors, on alkaline protease activity were investigated to further characterize the enzyme. The crude alkaline protease was pre-incubated with the above-mentioned chemicals for $1 \mathrm{~h}$ at $30^{\circ} \mathrm{C}$; afterwards the residual activity $(\%)$ was tested by standard proteolytic activity assay.}

\section{Result and discussion}

\subsection{Determination of the specific growth rates}

The first sub-culture to be used as the inoculum for the actual fermentation was prepared by transferring a loop-full of culture of each strain from fresh Horikoshii agar plate, into $25 \mathrm{ml}$ Horikoshii broth media and incubated at $37^{\circ} \mathrm{C}$ and $180 \mathrm{rpm}$ for $24 \mathrm{~h}$. During this time period, samples were taken for viable cell count and optical density (data not shown), in order to estimate the specific growth rates. The inoculum concentration for the actual fermentation of each strain was based on the optical density at the end of the exponential phase, corresponding to $5 \%$ $(\mathrm{v} / \mathrm{v})$. The aim was to standardize the inoculum amount for each experiment based on the growth rate of the first subculture. The specific growth rates were calculated from the slope of the loga- 
rithmic phase as $0.49,0.60$, and $0.70 \mathrm{~h}^{-1}$ for I18, L18 and L21, respectively. According to these, Bacillus sp. L21 was the strain with highest specific growth rate.

\subsection{Effect of the incubation temperature}

The effect of the incubation temperature on the proteolytic activity was determined by inoculating $5 \%$ inoculum of each culture into $50 \mathrm{ml}$ of Horikoshii medium (in $250 \mathrm{ml}$ of Erlenmeyer flask) and incubating at $30,37,45$ and $55^{\circ} \mathrm{C}$ at $180 \mathrm{rpm}$ for $96 \mathrm{~h}$. Based on the maximum protease activities (Table 1), strain I18 has temperature optima at $30^{\circ} \mathrm{C}$ whereas strains L18 and L21 have at $37^{\circ} \mathrm{C}$ (additional experiments performed using strain $\mathrm{I} 18$ revealed that the optimum temperature was not below $30{ }^{\circ} \mathrm{C}$; data not shown). The optical density results presented on the same table indicated that, for strains I18 and L18, there was an inverse relationship between the enzyme synthesis (based on the specific protease activities) and cell growth for the given temperatures. Only at $45^{\circ} \mathrm{C}$, strain L18 with a very low optical density and protease activity opposed this statement, which could be due to slower cell growth at this temperature producing therefore less enzyme. According to these data, one could conclude that protease enzyme is a non-growth related product, which is common in many microbial enzyme fermentations. For strain L21 an optimum temperature of $37^{\circ} \mathrm{C}$ promoted cell growth as well as enzyme synthesis compared to the other temperature ranges studied. One should also take into account that the enzyme synthesized at $45^{\circ} \mathrm{C}$ and higher temperatures might face the risk of denaturation of the protein, as well as degradation due to the proteolytic activity of the protease produced. This could contribute to the lower activity results obtained in this study as well. Therefore, it is very difficult to make solid justi-

Table 1

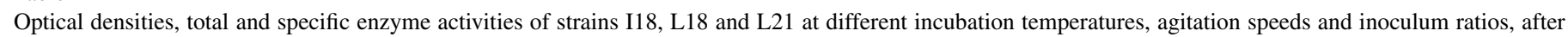
$96 \mathrm{~h}$ of incubation

\begin{tabular}{|c|c|c|c|c|c|}
\hline Strains & Factors & Levels & Optical density & Protease activity $(\mathrm{U} / \mathrm{ml})$ & Specific protease activity (U/mg protein) \\
\hline \multirow[t]{12}{*}{ I18 } & \multirow[t]{4}{*}{ Temperature $\left({ }^{\circ} \mathrm{C}\right)$} & 30 & 3.52 & 132.2 & 27.3 \\
\hline & & 37 & 4.56 & 128.0 & 14.9 \\
\hline & & 45 & 4.26 & 127.1 & 16.3 \\
\hline & & 55 & No growth & No growth & No growth \\
\hline & \multirow[t]{4}{*}{ Agitation (rpm) } & 100 & 5.08 & 159.5 & 31.97 \\
\hline & & 180 & 4.56 & 128.0 & 14.87 \\
\hline & & 250 & 3.24 & 141.4 & 20.73 \\
\hline & & 325 & 4.12 & 134.6 & 15.42 \\
\hline & \multirow[t]{4}{*}{ Inoculum (v/v, \%) } & 1 & 6.74 & 51.9 & 6.9 \\
\hline & & 2.5 & 6.63 & 26.7 & 3.7 \\
\hline & & 5 & 3.52 & 132.2 & 27.3 \\
\hline & & 10 & 4.99 & 28.3 & 3.8 \\
\hline \multirow[t]{12}{*}{ L18 } & \multirow[t]{4}{*}{ Temperature $\left({ }^{\circ} \mathrm{C}\right)$} & 30 & 5.47 & 133.8 & 28.9 \\
\hline & & 37 & 4.97 & 222.1 & 49.0 \\
\hline & & 45 & 2.56 & 85.0 & 18.3 \\
\hline & & 55 & No growth & No growth & No growth \\
\hline & \multirow[t]{4}{*}{ Agitation (rpm) } & 100 & 5.15 & 161.2 & 19.49 \\
\hline & & 180 & 4.97 & 222.1 & 49.02 \\
\hline & & 250 & 3.78 & 142.3 & 16.55 \\
\hline & & 325 & 5.09 & 135.3 & 13.61 \\
\hline & \multirow[t]{4}{*}{ Inoculum (v/v, \%) } & 1 & 3.58 & 61.3 & 7.4 \\
\hline & & 2.5 & 3.85 & 42.7 & 4.9 \\
\hline & & 5 & 4.97 & 222.1 & 49.0 \\
\hline & & 10 & 2.67 & 36.8 & 3.7 \\
\hline \multirow[t]{12}{*}{ L21 } & \multirow[t]{4}{*}{ Temperature $\left({ }^{\circ} \mathrm{C}\right)$} & 30 & 2.72 & 163.0 & 42.7 \\
\hline & & 37 & 5.32 & 216.3 & 60.1 \\
\hline & & 45 & 4.66 & 92.1 & 14.6 \\
\hline & & 55 & No growth & No growth & No growth \\
\hline & \multirow[t]{4}{*}{ Agitation (rpm) } & 100 & 5.06 & 106.7 & 16.94 \\
\hline & & 180 & 5.32 & 216.3 & 60.09 \\
\hline & & 250 & 2.90 & 94.2 & 8.91 \\
\hline & & 325 & 4.35 & 186.0 & 30.24 \\
\hline & \multirow[t]{4}{*}{ Inoculum (v/v, \%) } & 1 & 5.47 & 161.6 & 21.8 \\
\hline & & 2.5 & 5.12 & 167.7 & 22.3 \\
\hline & & 5 & 5.32 & 216.3 & 60.0 \\
\hline & & 10 & 5.52 & 176.8 & 25.1 \\
\hline
\end{tabular}



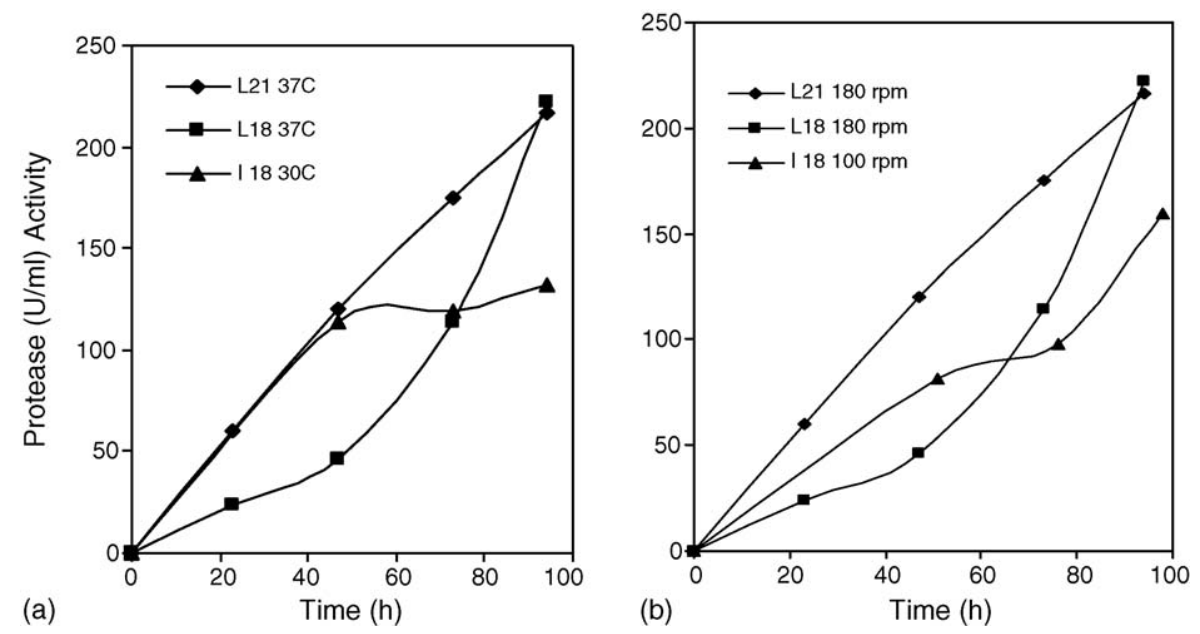

Fig. 1. Protease enzyme profiles of the strains I18, L18 and L21 at (a) optimum temperatures; (b) optimum agitation speeds.

fications according to the given data. From the enzyme profiles (Fig. 1a), it was observed that, L18 and L21 reached almost the same enzyme level; however, the rate of enzyme synthesis was much faster with strain L21 compared to the others. Considering either total or specific enzyme activities, in both cases strain I18 was the less performing strain. This difference among the strains could be attributed to the sources of isolation, where I18 was isolated from soil and L18 and L21 were isolated from leather by-products. No growth was detected for any of the strains at $55^{\circ} \mathrm{C}$.

A comparison of the literature on the characteristics of alkaline Bacillus strains producing alkaline proteases revealed that most of the alkaline Bacillus strains were of mesophilic type with temperature optima of $30-37^{\circ} \mathrm{C}$. With this regard, these strains were in agreement with the literature $[1,2,11,14-16]$.

\subsection{Effect of agitation speed}

The effect of the agitation speed on the protease enzyme synthesis was determined, by inoculating $5 \%$ of each first subculture into $50 \mathrm{ml}$ of Horikoshii media and incubating at $37^{\circ} \mathrm{C}$ and 100, 180, 250 and $325 \mathrm{rpm}$ under the same fermentation conditions. Based on the total and specific protease activities (Table 1), $100 \mathrm{rpm}$ was determined to be the optimum agitation speed for strain I18 and $180 \mathrm{rpm}$ for the others (L18 and L21). In the correlation of the agitation speed to the cell growth, it was observed that for all three strains, there was a trend where an increase in agitation speed up to $250 \mathrm{rpm}$ resulted in low optical cell density, beyond which the cell densities started to increase with an increase in the agitation speed to $325 \mathrm{rpm}$. This could be explained besides the characteristics of the strain, with a better oxygen and nutrient transfer rate at this speed, promoting more cell growth. It was obvious from the given data, that all three strains did not require higher agitation speeds for enzyme synthesis, probably due to the less requirement for oxygen. This phenomena again brings up the issue of non-growth related product formation, observed in many microbial enzyme fermentations as discussed in Section 3.2. Based on the total protease activities, L18 was the dominant strain. However, based on specific activities this pictures changed, where L21 became the superior strain with $18.4 \%$ and $46.7 \%$ more specific protease activity than the strains I18 and L18, respectively. This was also supported with the enzyme profiles at optimum agitation speeds shown in Fig. 1b. In the reported literature, most of the agitations speeds used for this type of strains are between 180 and $220 \mathrm{rpm}$. Therefore, our results support these findings. $[1,3,4,17]$.

\subsection{Effect of inoculation ratio}

To determine the effect of inoculation ratio, $50 \mathrm{ml}$ of the Horikoshii media was inoculated, with 1\%, 2.5\%, 5\% and $10 \%$ $(\mathrm{v} / \mathrm{v})$ of the first subculture of each strain. Strain I18 was incubated at $100 \mathrm{rpm}$ and $30^{\circ} \mathrm{C}$; L18 and L21 were incubated at $180 \mathrm{rpm}$ and $37^{\circ} \mathrm{C}$, since these were the predetermined optimum conditions. An increase in the inoculation ratio from $1 \%$ to $5 \%$ decreased the optical cell density of the strain I18, beyond where a raise was observed after $10 \%$ inoculation (Table 1). An explanation for this would be that, $1 \%$ or $2.5 \%$ inoculation ratio did not cause an overload of cells facing nutrient or oxygen limitation. However, after 5\% this changed, where this concentration became probably a threshold changing the pathways of cell growth towards enzyme synthesis. A 10\% inoculation however, was so high where the nutrients were consumed faster and overall resulted into less cell growth compared to $1 \%$ and $2.5 \%$. But this seemed to be still within the pathways towards cell growth rather than enzyme synthesis, therefore resulted into lower enzyme activity. The effect of inoculation ratio on strain L21 seemed not to be significant on cell growth, because almost same optical cell densities were obtained at all inoculation levels used. An increase to $10 \%$ decreased the cell growth significantly for strain L21. It was obvious that, the inoculation ratio had different impacts on cell growth and enzyme synthesis depending on the characteristics of the strains. Based on these findings, the optimum inoculation ratio was determined as $5 \%(\mathrm{v} / \mathrm{v})$ for all three strains considering protease activities. Strain L21 was 
Table 2

Total protease activities of strains I18, L18 and L21 at different incubation times

\begin{tabular}{lccc}
\hline Strain & \multicolumn{2}{l}{ Protease activity $(\mathrm{U} / \mathrm{ml})$} \\
\cline { 2 - 4 } & $73 \mathrm{~h}$ & $96 \mathrm{~h}$ & $125 \mathrm{~h}$ \\
\hline I18 & 97.5 & 159.5 & 81.3 \\
L18 & 114.0 & 222.1 & 243.7 \\
L21 & 175.2 & 216.3 & 224.0 \\
\hline
\end{tabular}

chosen as the best performing strain, based on the comparisons with respect to total and specific enzyme activities at this optimum ratio. Since, the specific enzyme activity gives an indirect indication on the purity of the enzyme, this value is desired to be as high as possible. Therefore, L21 was thought to produce less side by-products than the other two strains. An inoculation ratio of 2-5\% was an optimum value for Bacillus type of strains reported in the literature, which supported our findings $[14,18]$.

\subsection{Effect of incubation time}

In order to determine the optimum incubation time for maximum enzyme production, $50 \mathrm{ml}$ of Horikoshii media inoculated with $5 \%(\mathrm{v} / \mathrm{v})$ of the first subculture of each strain, was incubated at the predetermined optimum conditions (I18: $30^{\circ} \mathrm{C}$ and $100 \mathrm{rpm}$; L18 and L21: $37^{\circ} \mathrm{C}$ and $\left.180 \mathrm{rpm}\right)$ for 73,96 and $125 \mathrm{~h}$. According to the results taken at different time intervals (Table 2), it was determined that the optimum incubation time for all there strains was around $96 \mathrm{~h}$ even though, numerically from the data the highest activity was achieved for strain L18 and L21 at $125 \mathrm{~h}$. This conclusion was based on the estimation of the activity gain of $3.3 \%$ for strain $\mathrm{L} 21$ and $8.8 \%$ for $\mathrm{L} 18$ versus a time extension of $29 \mathrm{~h}$. In order to make right judgments and decisions, one has to estimate the cost, whether extending the fermentation time and therefore increasing the operating cost would be compensated by the extra gain that would be obtained through the extra enzyme yield. Our experience is that, shorter fermentation time would be much more profitable in industrial scale compared to the extra enzyme yield. The decrease observed in the protease activity of strain I18 at $125 \mathrm{~h}$ could be because of the hydrolysis of the enzyme by the protease itself. The literature reports a broad incubation time ranging from 24 to $120 \mathrm{~h}$ for Bacillus strains, which includes our range as well $[14,19,20]$.

\subsection{Effect of media $p H$}

The effect of initial media $\mathrm{pH}$ was determined for strains L18 and L21, by adjusting the Horikoshii media to different initial $\mathrm{pH}$ using $6 \mathrm{~N} \mathrm{NaOH}$. Inoculation was performed with 5\% (v/v) inoculum of each subculture and incubated at $37^{\circ} \mathrm{C}$ and $180 \mathrm{rpm}$ for $96 \mathrm{~h}$. I18 was not taken in this set of experiment since, L18 and L21 strains were the promising strains for high protease activities and further study was performed on these two strains. The protease activity and optical density profiles (Fig. 2) at different $\mathrm{pH}$ values demonstrated that, $\mathrm{L} 21$ has a much broader $\mathrm{pH}$ range than L18. This suggested that strain L18 was a strict alkaline with a narrow $\mathrm{pH}$ range, whereas $\mathrm{L} 21$ might range to be

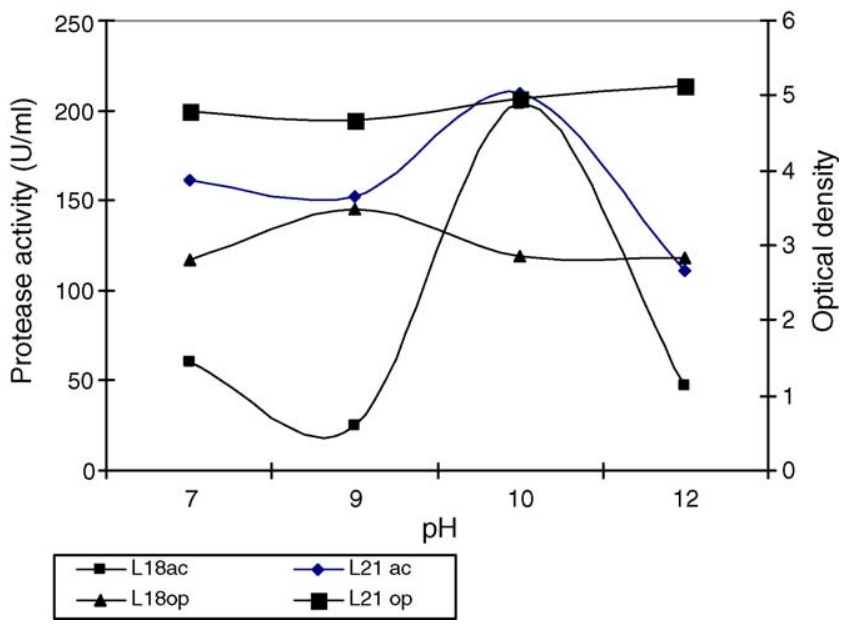

Fig. 2. Growth $\mathrm{pH}$ profiles of $\mathrm{L} 18$ and $\mathrm{L} 21$ at $37^{\circ} \mathrm{C}$ and $180 \mathrm{rpm}$ in standard Horikoshii media incubated for $96 \mathrm{~h}$ ("ac" stands for activity; "op" stands for optical density absorbance).

a neutral to alkaline. Strain L21 seemed to be much more stable against $\mathrm{pH}$ changes with respect to protease activity; however, same conclusion could not be drawn for the other strain. Cell growth seemed to be effected by $\mathrm{pH}$ changes similarly for both strains; even so L18 has overall a lower optical cell density than L21. With this regard L21 seemed to be a better candidate for further study.

\subsection{Yield factors at optimum conditions}

Biomass and product yield factors were estimated using the protease activities reported in Table 1 and carbon utilization profiles in Fig. 3. The predetermined optimum conditions as given in Section 3.5 were used with $96 \mathrm{~h}$ of incubation. The inoculation ratio for all three strains was $5 \%(\mathrm{v} / \mathrm{v})$. The initial $\mathrm{pH}$ of the Horikoshii media was 10 , which was already determined to be the optimum $\mathrm{pH}$ for L18 and L21. In the calculations of the yield factors maintenance effects and endogenous metabolism were neglected, the biomass was the dry cell weight of the culture. An inverse relationship between biomass and product yield was observed (Table 3 ). This relation was very much pronounced

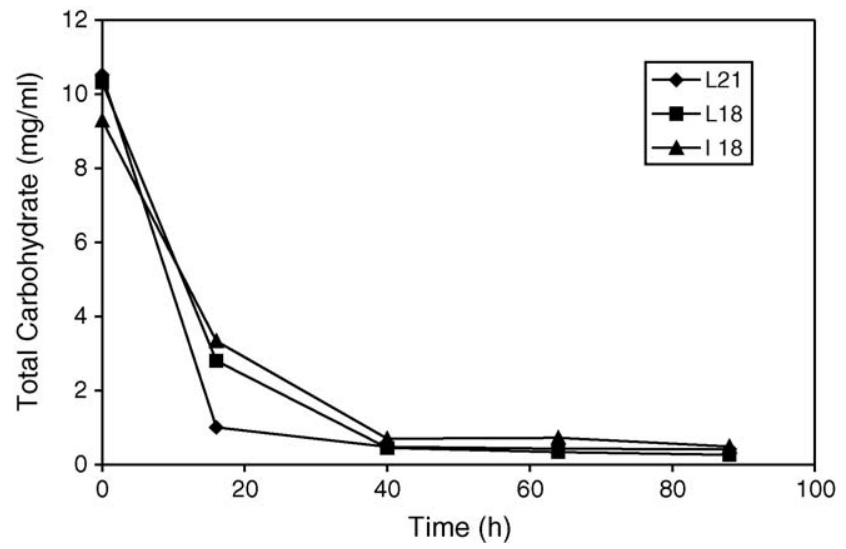

Fig. 3. Total carbohydrate profiles of I18, L18 and L21 at optimized fermentation conditions. 
Table 3

Biomass and product yields of strains I18, L18 and L21 at optimized conditions after $96 \mathrm{~h}$ of incubation

\begin{tabular}{lll}
\hline Strain & $\begin{array}{l}\text { Biomass }\left(Y_{\mathrm{X} / \mathrm{S}}\right)(\mathrm{g} \text { dcell/g } \\
\text { glucose })\end{array}$ & $\begin{array}{l}\text { Product yield }\left(Y_{\mathrm{P} / \mathrm{S}}\right) \\
\text { (U protease/g glucose })\end{array}$ \\
\hline I18 & 0.017 & 0.014 \\
L18 & 0.011 & 0.022 \\
L21 & 0.023 & 0.021
\end{tabular}

for strain L18 compared to the other two. Therefore, one could conclude that the enzyme production was not growth related. However, for the other two organisms (I18 and L21) fermentation conditions favoring the growth seemed not to adversely effect the product formation. These results were confirmed with carbohydrate utilization profiles (Fig. 3), which showed that the carbohydrate was faster utilized in strain L21 compared to the others. This brought up the issue, whether controlled carbohydrate supply at the end of $40 \mathrm{~h}$ would increase product formation of this strain (L21) further or not. Therefore, this would be a task to be studied in future. Another drawback would be that faster carbohydrate consumption would increase raw material cost. Therefore, a balance between the cost of the raw material and the gain from the product yield has to be established. With this respect strain L18 seemed to be a more efficient strain with less carbohydrate consumption but still with higher product yield. Since, this strain resulted in lower specific activity with less $\mathrm{pH}$ stability, it was not considered for further study. Comparison among the strains demonstrated that, strain L21 was the strain with high biomass and product yield. The biomass and product yield for this strain was determined as $0.023 \mathrm{~g}$ cell $/ \mathrm{g}$ glucose and $0.021 \mathrm{U} / g$ glucose, respectively.
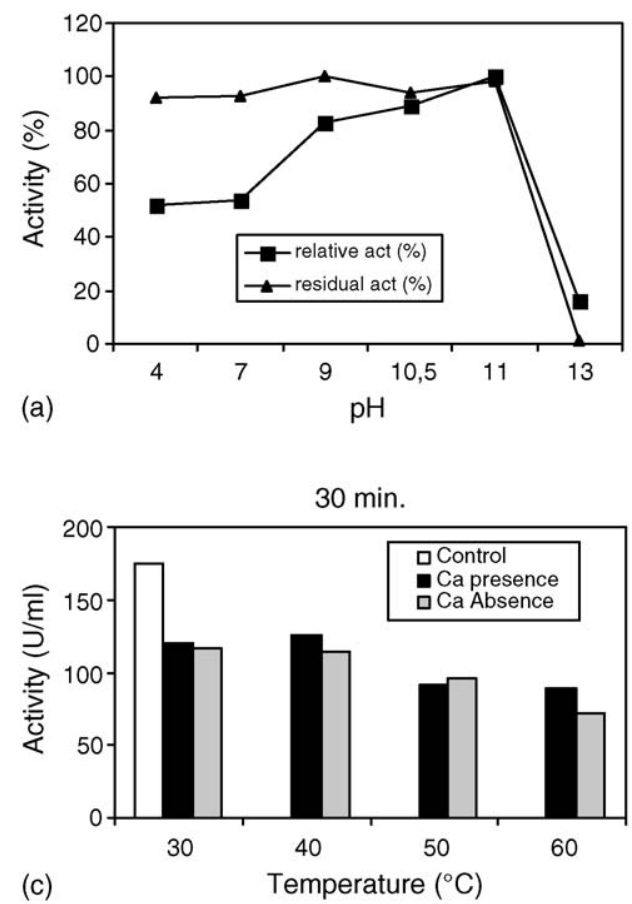

Table 4

Effect of various reagents on activity of alkaline protease

\begin{tabular}{lc}
\hline Agent & Residual activity (\%) \\
\hline Control & 100.0 \\
$\mathrm{H}_{2} \mathrm{O}_{2}(5 \%, \mathrm{v} / \mathrm{v})$ & 81.8 \\
$\mathrm{H}_{2} \mathrm{O}_{2}(15 \%, \mathrm{v} / \mathrm{v})$ & 93.6 \\
$\mathrm{EDTA}(0.01 \mathrm{M})$ & 92.8 \\
$\mathrm{CaCl}_{2}(0.01 \mathrm{M})$ & 89.7 \\
PMSF $(0.01 \mathrm{M})$ & 1.5 \\
\hline
\end{tabular}

\subsection{Characterization of the crude enzyme obtained from L21}

Since strain L21, demonstrated a higher potential for alkaline protease activity, it was world wide to further characterize this enzyme and determine its potential applications. Therefore, a preliminary study, as outlined in Section 2 on the characterization of this enzyme was carried out. According to this study (Fig. 4 and Table 4), it was determined, that this enzyme was bleach stable and belonged to the serine alkaline family with an optimum temperature of $60^{\circ} \mathrm{C}$ and a pH of 11 . This conclusion was based on the findings that this enzyme retained $93 \%$ of its activity after $1 \mathrm{~h}$ of incubation with EDTA and was completely inhibited by $0.01 \mathrm{M}$ PMSF. As it is known EDTA is a specific inhibitor of metallo-type protease and PMSF is known to sulphonate the essential serine residue in the active site of the protease, resulting in a total loss of enzyme activity [21]. This inhibition profile suggested that the protease produced from Bacillus sp. L21 belongs to the family of serine proteases. Many of the Bacillus-derived alkaline proteases reported so far, belong to the class of serine proteases [22]. In addition, the stability of
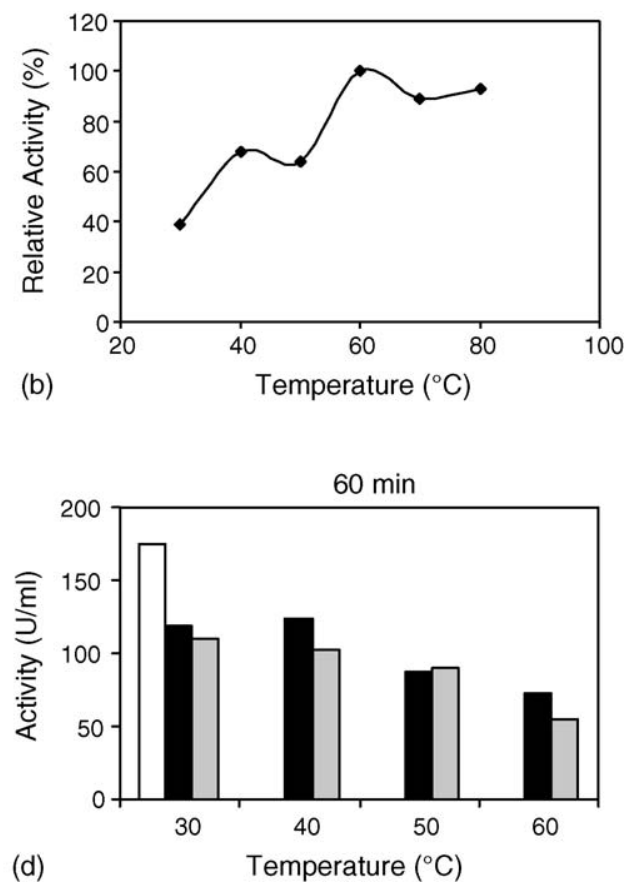

Fig. 4. (a) Effect of $\mathrm{pH}$ on activity and stability of Bacillus sp. L21; (b) effect of temperature on activity; (c) effect of temperature on the stability at 30 min incubation; (d) effect of temperature on the stability at 60 min incubation. 
the enzyme in presence of EDTA is advantageous for its use as a detergent additive.

The crude protease retained $90 \%$ of its activity at $80{ }^{\circ} \mathrm{C}$ and was stable over a broad $\mathrm{pH}$ range from 4 to 11 . It was also thermostable over a temperature range of $30-50{ }^{\circ} \mathrm{C}$, retaining $30 \%$ of its activity at $60{ }^{\circ} \mathrm{C}$ after $1 \mathrm{~h}$ of incubation in the absence of $\mathrm{Ca}^{2+}$ ion. In the process of detergent formulation, where alkaline proteases are commonly added, chelating agents are included to overcome the problem of water hardness. In the presence of such chelating agents; however, the $\mathrm{Ca}^{2+}$ from the weak-binding site of the alkaline protease can easily be stripped-off thus greatly affecting the thermal stability of the detergent enzyme under application conditions. Therefore, enzymes such as the one introduced in this study, where the effect of $\mathrm{Ca}^{2+}$ for stability at low temperatures below $40^{\circ} \mathrm{C}$ was not significant, could offer tremendous benefit for detergent application.

Another detail study on the growth medium (using various carbon, nitrogen and elements) optimization for this strain was carried out using response surface methodology. Soybean meal at $3 \mathrm{~g} / \mathrm{l}$, maltose 50 between the ranges of 30 and $40 \mathrm{~g} / \mathrm{l}$ and tween 80 at $0.35 \mathrm{~g} / \mathrm{l}$ produced an activity of $307 \mathrm{U} / \mathrm{ml}$, which corresponded to $40 \%$ increase. [23].

\section{Conclusion}

In this paper three Bacillus strains I18, L18 and L21 isolated from local environment of Izmir Turkey region, with possible alkaline protease activity were compared and their fermentation conditions (temperature, agitation speed, inoculum concentration, incubation time and initial media $\mathrm{pH}$ ) were optimized. Based on the results, strain I1 8 had optimum conditions as $30^{\circ} \mathrm{C}$, $100 \mathrm{rpm}$, and 5\% inoculum with an incubation time of $96 \mathrm{~h}$. Whereas these data were, $37^{\circ} \mathrm{C}$ and $180 \mathrm{rpm}, 5 \%$ inoculum and $96 \mathrm{~h}$ of incubation time for L18 and L2. In all experiment I18 strain was the less performing strain. L18 and L21 showed a closer performance with the main difference in their $\mathrm{pH}$ profiles. Taking all the results into account, L21 strain was the strain of choice for further optimization study and a potential candidate with alkaline proteolytic activity for future industrial applications. Based on the preliminary characterization of the crude enzyme, it was determined that, this enzyme was a bleach stable alkaline protease belonging to the serine alkaline family. The optimum $\mathrm{pH}$ and temperature were determined as 11 and $60^{\circ} \mathrm{C}$.

Overall, the highest protease activity $(222 \mathrm{U} / \mathrm{ml})$ achieved in this study was lower compared to the regular proteases used industrially, which are mainly in the purified form. One should also take into account that the present protease activity in this study is from a crude enzyme, obtained purely from a strain, which did not go through any strain improvement study in this regard. Furthermore, a characterization after purification and possible application study of this enzyme would be a task to do in future. With this respect this paper, is just an initial study conducted on three strains producing alkaline proteases with possible novel characteristics, carrying the potential to be candidate for industrial use. Considering the biodiversity of our environment it is highly important to discover new enzymes from isolates living under extreme conditions, which could have novel properties that could contribute to the current enzyme potential.

\section{Acknowledgements}

Financial support of Izmir Institute of Technology and the kind supply of the strains by the Biology Departments of Izmir Institute of Technology and Ege University are gratefully acknowledged.

\section{References}

[1] Banerjee CU, Sani RK, Azmi W, Soni R. Thermostable alkaline protease from Bacillus brevis and its characterization as a laundry detergent additive. Process Biochem 1999;35:213-9.

[2] Joo HS, Kumar CG, Park GC, Paik SR, Chang CS. Oxidant and SDS stable alkaline protease from Bacillus clausii I-52: production and some properties. J Appl Microbiol 2003;95:267-72.

[3] Gupta R, Beg QK, Lorenz P. Bacterial alkaline proteases: molecular approaches and industrial applications. Appl Microbiol Biotechnol 2002;59:15-32.

[4] Joo HS, Kumar CG, Park GC, Kim KT, Paik SR, Chang CS. Optimization of the production of an extra cellular alkaline protease from Bacillus horikoshii. Process Biochem 2002;38:155-9.

[5] Rebecca BD, Pena-Vera MT, Diaz Castaneda M. Production of fish protein hydrolysates with bacterial proteases, yield and nutritional value. J Food Sci 1991;56:309-14.

[6] O'Meara GM, Munro PA. Selection of a proteolytic enzyme to solubilize lean beef tissue. Enzyme Microb Technol 1984;6:181-5.

[7] Tanimoto SY, Tanabe S, Watanabe M, Arai S. Enzymatic modification of zein to produce a non-bitter peptide fraction with a very Fisher ratio for patients with hepatic encephalopathy. Agric Biol Chem 1991;55:1119-23.

[8] Godfrey T, West S. Introduction to industrial enzymology. In: Industrial enzymology. 2nd ed. New York: Stocholm Press; 1996. p. 1-7.

[9] Horikoshii K. Extracellular enzymes. Isolation procedures for alkaline enzymes. In: Alkaliphiles. Tokyo: Kodensha Ltd.; 1999. p. 147.

[10] Akbalik G, Günes H, Yavuz E, Yasa I, Harsa S, Elmacı SZ, et al. Identification of extracellular enzyme producing alkalophilic bacilli from Izmir province by 16S-ITS rDNA RFLP. J Appl Microbiol 2004:766-73.

[11] Takami H, Akiba T, Horikaoshi K. Production of extremely thermostable alkaline protease from Bacillus sp. No. AH-101. Appl Microbiol Biotechnol 1989;30:120-4.

[12] Lowry OH, Rosebrough NJ, Farr AL, Randall JR. Protein measurement with the folin phenol reagent. J Biol Chem 1951;193:265-75.

[13] DuBois M. Colorimetric method for determination of sugars and related substances. Anal Chem 1956;28(3):350-6.

[14] Mabrouk SS, Hashem AM, El-Shayeb NMA, Ismail MS, Abdel-Fattah AF. Optimization of alkaline protease productivity by Bacillus licheniformis ATCC 21415. Bioresour Technol 1999;69:155-9.

[15] Çalık P, Özçelik ŞÖ, Çalık G, Özdamar TH. Enzyme ion exchanger interactions in serine alkaline protease production: theory, equilibria and kinetics. Biochem Eng J 2002;3623:1-12.

[16] Puri S, Khalil O, Gupta R. Optimization of alkaline protease production from Bacillus sp. by response surface methodology. Curr Microbiol 2002;44:286-90.

[17] Liu BL, Tzeng YM. Optimization of growth medium for the production of spores from Bacillus thuringiensis using surface response methodology. Bioprocess Eng 1998;18:413-8.

[18] Kanekar PP, Nilegaonkar SS, Sarnaik SS, Kelkar AS. Optimization of protease activity of alkaliphilic bacteria isolated from an alkaline lake in India. Bioresour Technol 2002;85:87-93.

[19] Beg QK, Gupta R. Purification and characterization of an oxidation stable, thiol-dependent serine alkaline protease from Bacillus mojavensis. Enzyme Microb Technol 2003;32:294-304. 
[20] Chu IM, Lee C, Li TS. Production and degradation of alkaline protease in batch cultures of Bacillus subtilis ATCC 14416. Enzyme Microb Technol 1992;14:755-61.

[21] Kumar CG. Purification and characterization of a thermostable alkaline protease from alkalophilic Bacillus pumilus. Lett Appl Microbiol 2002;34:13-7.
[22] Gessesse A. The use of nug meal as a low-cost substrate for the production of alkaline protease by the alkaliphilic Bacillus sp. AR-009 and some properties of the enzyme. Bioresour Technol 1997;62:59-61.

[23] Tari C, Genckal H, Tokatli F. Optimization of a growth medium using a statistical approach for the production of an alkaline protease from a newly isolated Bacillus sp. L21. Process Biochem, in press. 